\title{
Malaria: Probably locally acquired in Toronto, Ontario
}

\author{
Mahin Baqi MD FRCPC, Ken Gamble MD, Jay S Keystone MD FRCPC, Kevin C Kain MD FRCPC
}

\begin{abstract}
M Baqi, K Gamble, JS Keystone, KC Kain. Malaria: Probably locally acquired in Toronto, Ontario. Can J Infect Dis 1998;9(3):183-184.

Although local acquisition of malaria has been reported in the United States, no such cases have been reported in Canada. The authors report a case of Plasmodium vivax malaria in a patient with no travel to a malarious area in the preceding nine years, and postulate local acquisition as the most likely explanation for her infection. The only other plausible alternative explanation of equal biological interest would be that this case represents the latest relapse of vivax malaria ever reported.
\end{abstract}

Key Words: Malaria, Plasmodium vivax, Relapse

\begin{abstract}
Malaria : hypothèse d'une contamination indigène à Toronto, en Ontario
RÉSUMÉ : Bien que des cas de malaria indigène aient été signalés aux États-Unis, aucun cas de cette sorte n'a été signalé au Canada. Les auteurs signalent un cas de malaria à Plasmodium vivax chez une patiente qui n'a pas voyagé dans une région à malaria au cours des neuf dernières années, et émettent l'hypothèse d'une contamination indigène comme la source la plus probable d'infection de cette patiente. L'autre explication possible d'intérêt biologique similaire serait que ce cas représente la rechute la plus tardive de malaria à P.vivax jamais signalée auparavant.
\end{abstract}

$M^{a}$ alaria was endemic in many areas of Canada and the United States during the 19th and early 20th centuries. With urbanization and improved living conditions indigenous transmission was interrupted in the 1950s. From 1957 to present, at least 80 cases of locally acquired malaria have been reported in the United States (1). There have been, to our knowledge, no indigenously acquired cases of malaria reported as far north as Canada (Laboratory Centre for Disease Control [LCDC], Ottawa, Canada). We report the first case of Plasmodium vivax malaria probably locally acquired in Toronto, Ontario.

\section{CASE PRESENTATION}

On September 29, 1996, a 47-year-old woman of Indian descent was seen in a local clinic following a $24 \mathrm{~h}$ history of fever, chills and myalgias. A malaria smear was requested although there had not been any history of travel to a malaria endemic region in the previous nine years. Several days later, her family physician received the results of the malaria smear that indicated $0.2 \%$ parasitemia with $P$ vivax. A careful history was repeated and again revealed no travel to any area with known malaria transmission. Smears and blood from September 29, 1996 were obtained for review, and $P$ vivax was confirmed by reference microscopy and by polymerase chain reaction (PCR)-based methods (2,3). The patient's symptoms apparently resolved spontaneously without a history of the use of specific anti-malarial therapy. Thick and thin smears, and PCR were repeated on October 29 and were negative. Physical examination on October 29 was unremarkable. Potential explanations for spontaneous resolution of infection include undisclosed treatment with an antimalarial or antimicrobial agent, or clearance secondary to an anamnestic immune response from previous episodes of malaria.

The patient was born in the Punjab, India and emigrated to

Tropical Disease Unit, Division of Infectious Diseases, Department of Medicine, The Toronto Hospital and University of Toronto, Toronto, Ontario

Correspondence: Dr KC Kain, Director, Tropical Disease Unit, The Toronto Hospital, 200 Elizabeth Street, Toronto, Ontario

M5G 2C4. Telephone 416-340-3535, fax 416-595-5826, e-mail kkain@torhosp.toronto.on.ca

Received for publication October 22, 1997. Accepted February 10, 1998 
Canada in 1980. She reported that she had experienced multiple bouts of malaria while growing up in her homeland. Her last visit to India was from September to November 1987. She received no chemoprophylaxis but remained well during and after her trip. There was a remote history of a blood transfusion in the early 1970s during thyroid surgery, but no recent blood transfusions and no history of intravenous drug use. She lived in Brampton, a suburb of Toronto, $9 \mathrm{~km}$ from an international airport. In early September, she had relatives from India who visited her home. She remembered experiencing many mosquito bites throughout the summer months. The average ambient temperatures for Toronto in August and September 1996 were $20.7^{\circ} \mathrm{C}$ and $16.5^{\circ} \mathrm{C}$, respectively. The average temperature in September was $1.3^{\circ} \mathrm{C}$ above the 30 -year average of $15.2^{\circ} \mathrm{C}$. The average humidity in both months was high (93\%).

\section{DISCUSSION}

There are several potential explanations for this case of malaria in a nontransmission area. These include transmission via local anopheline vectors, transmission via anopheles imported by aircraft (airport malaria) or a relapse secondary to hypnozoites from vivax malaria acquired in 1987 or earlier.

Local transmission of malaria has been reported in the United States, with $P$ vivax accounting for $80 \%$ of cases (4). Local outbreaks of malaria have been identified in both rural and urban settings in California, Florida, New Jersey, New York, Texas and Michigan $(1,4)$. The basic requirement for local transmissions include persons with malaria gametocytes in their blood, competent vectors and weather conditions conducive to the survival of mosquitoes and parasite maturation. The suburb in which the patient lives has a large East Asian population that originally emigrated from the Indian subcontinent. There were 744 cases of malaria reported in Canada in 1996 , representing a $73 \%$ increase from 1994 . The majority of these cases occurred in the greater Toronto and Vancouver areas (LCDC, Ottawa, Canada). Recent immigrants or travellers from malarious areas returning to the same neighbourhood as the patient may have been sources of $P$ vivax gametocytes. Furthermore, Anopheles quadrimaculatus, a competent vector for $P$ vivax, is native to southern Ontario (5). Finally, the warm and extremely humid conditions persisting into September 1996 may have facilitated mosquito survival and malaria transmission.

The possibility of airport malaria is less likely given that the distance from the patient's home to the airport exceeded the 2 to $3 \mathrm{~km}$ flight range of anopheles (6) and rarity of non- stop flights from malaria-endemic regions to Toronto. An alternative explanation for this case could be the relapse of dormant hypnozoite stages of $P$ vivax from the liver into the blood, giving rise to symptomatic infection. However, these relapse forms would have to have been from an infection acquired at least nine years earlier while the patient was visiting India. This is an interesting and important possibility with potential implications for both malaria recognition in nonendemic areas and malaria control in malaria-endemic regions. However, this is perhaps a less likely scenario given that this case would exceed the longest previously reported vivax relapse (five years) by four years (7). Therefore, we consider local transmission of malaria the most plausible explanation for this case.

Although most malaria cases in Canada are travel-related, sporadic cases in the absence of risk factors may occur. It is possible that local malaria transmission may occur in communities with new immigrant populations from malaria-endemic areas and where sufficient densities of anopheles mosquitoes exist during summer months. This case demonstrates the importance of considering malaria in the differential diagnosis of fever of unknown origin, even in the absence of a history of recent travel to a malaria-endemic area.

ACKNOWLEDGEMENTS: This study was supported in part by a grant from The Physicians Services Incorporated Foundation (Kevin C Kain). Kevin C Kain is supported in part by a Career Scientist Award from the Ontario Ministry of Health.

\section{REFERENCES}

1. Centers for Disease Control and Prevention. Mosquitotransmitted malaria - Michigan, 1995. Mort Morb Wkly Rep 1996;45:398-400.

2. Kain KC, Brown AE, Mirabelli L, Webster HK. Detection of Plasmodium vivax by polymerase chain reaction in a field study. J Infect Dis 1993;168:1323-6.

3. Humar A, Ohrt C, Harrington MA, Pillai D, Kain KC. Parasight F test compared with the polymerase chain reaction and microscopy for the diagnosis of Plasmodium falciparum malaria in travelers. Am J Trop Med Hyg 1997;56:44-8.

4. Zucker JR. Changing patterns of autochthonous malaria transmission in the United States: A review of recent outbreaks. Emerg Infect Dis 1996;2:37-43.

5. Brok JK, Genese CA, BIoland PB, Zucker JR, Spitalny KC. Brief report: Malaria probably locally acquired in New Jersey. $\mathrm{N}$ Engl J Med 1994;331:22-3.

6. Isaacson M. Airport malaria: A review. Bull World Health Organ 1989;67:737-43.

7. Bruce-Chwatt LJ. The malaria parasites. In: Essential Malariology, 2nd edn. London: William Heinemann Medical Books, 1985:32. 


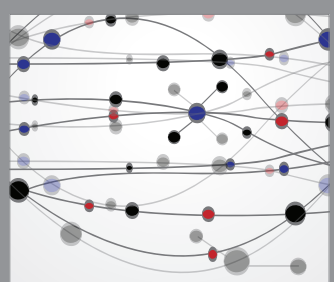

The Scientific World Journal
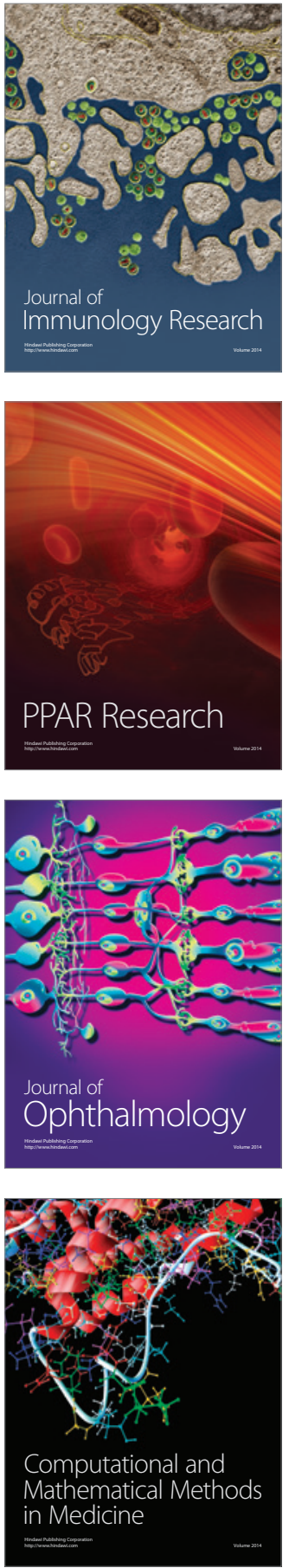

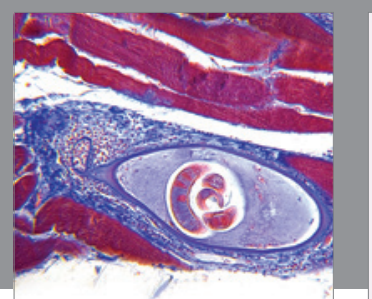

Gastroenterology Research and Practice

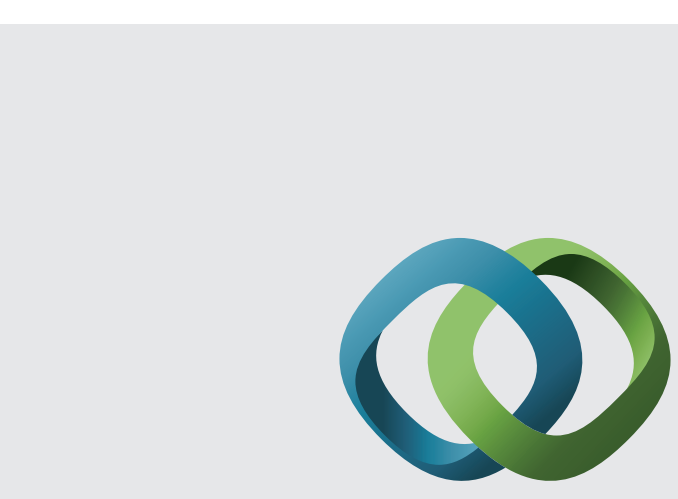

\section{Hindawi}

Submit your manuscripts at

http://www.hindawi.com
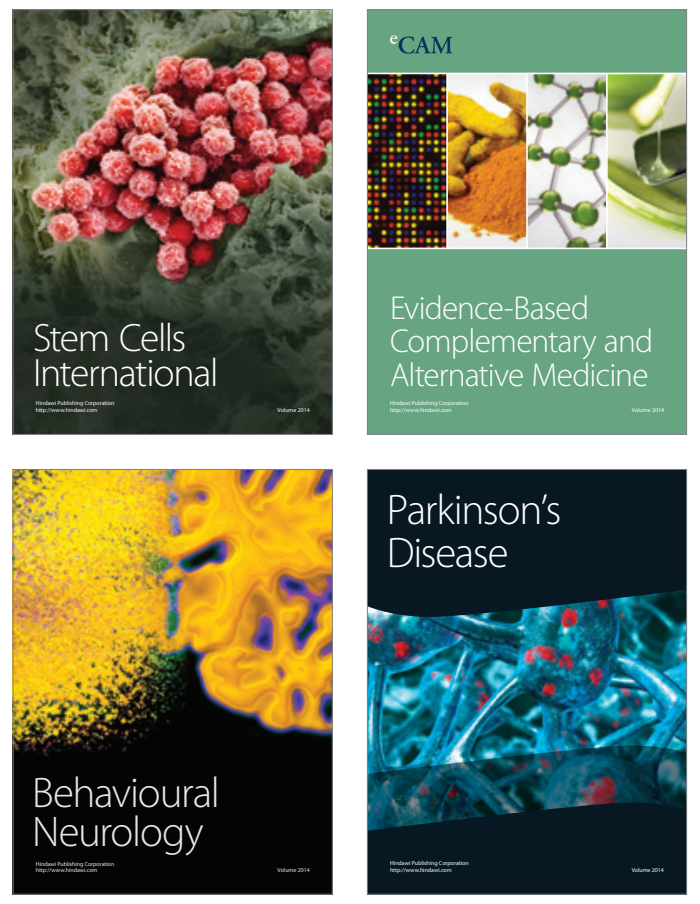
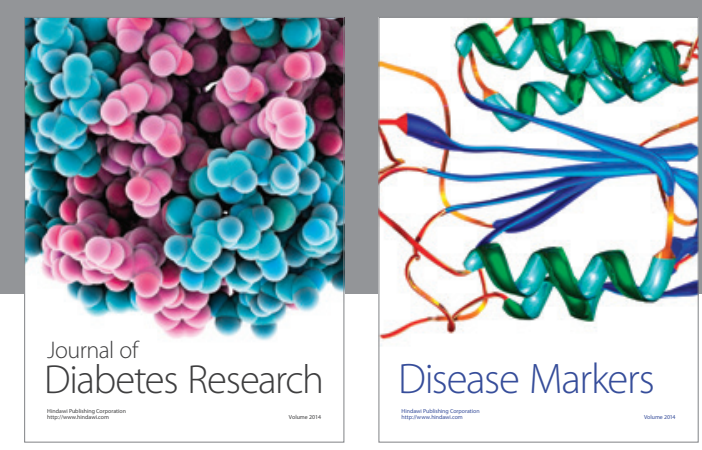

Disease Markers
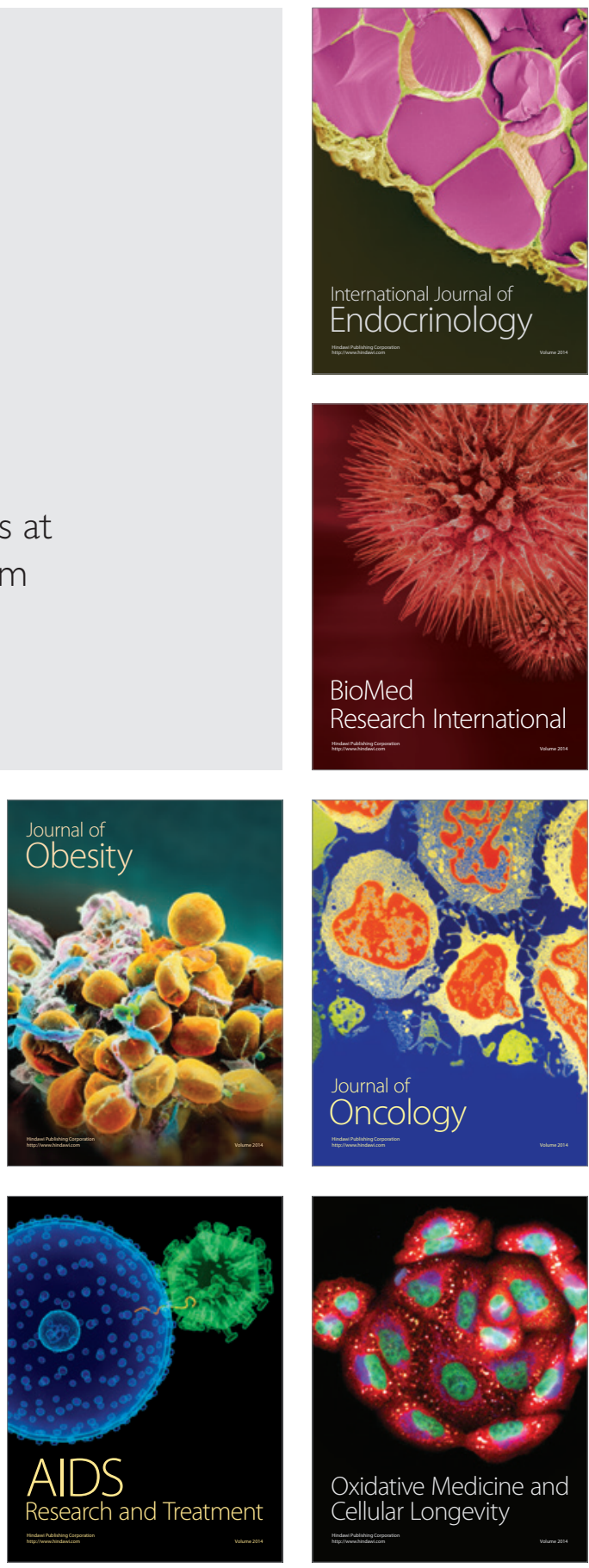